\title{
Targeting breast cancer vaccines to dendritic cells: improved immunological responses with less protein?
}

\author{
Anne C Armstrong and David E Gilham* \\ See related research by Wang et al., http://breast-cancer-research.com/content/14/2/R39
}

\begin{abstract}
The central goal of cancer immunotherapy is to control tumors through the mobilization of the patient's immune system. Vaccines targeting the Her2/neu proto-oncogene have been tested with some early encouraging responses in breast cancer. However, a more effective set of vaccines targeting specific immune cell subtypes may provide a more potent means to stimulate anti-tumor immunity. Dendritic cell-specific antibodies fused with the Her2/neu protein proved effective at generating immune responses in preclinical models. Importantly, only low amounts of protein vaccine were required to generate this response, which has potentially significant implications for the future clinical development of Her2/ neu-targeted vaccines and other vaccine targets.
\end{abstract}

Despite significant advances in the treatment of Her2/ neu-overexpressing breast cancer in the last few decades, the majority of patients with metastatic Her2/neu $u^{+}$ tumors ultimately succumb to their disease. Moreover, Her2/neu proto-oncogene has generally been associated with a poor clinical outcome; however, the overexpression of this cell surface growth factor receptor also provides a target that can be exploited for immunotherapeutics. Her2/neu-specific vaccines have been tested with a further refinement in the potential effectiveness of a protein vaccine described in a paper in the previous issue of Breast Cancer Research [1]. Moreover, support for the

*Correspondence: dgilham@picr.man.ac.uk

Clinical and Experimental Immunotherapy Group, School of Cancer and Enabling Sciences, University of Manchester, Manchester Academic Healthcare Science Centre, Paterson Institute for Cancer Research, Wilmslow Road, Withington, Manchester, M20 4BX, UK immunotherapy approach comes from the fact that monoclonal antibody therapy (trastuzumab) improves survival in both the adjuvant [2,3] and metastatic [4] setting. However, despite improvements in clinical outcome, metastatic breast cancer remains incurable and new treatments are needed.

The adoptive transfer of immune effector molecules (including monoclonal antibodies) and cells is termed passive vaccination. The success of this approach is likely dependent upon the persistence of the molecule/cell and its ability to engage the particular immunological process that results in a sufficient anti-tumor response. However, achieving sustained levels of immune effector molecules and cells in the patient is difficult and generally requires large amounts of protein or cells to be administered over a prolonged period of time.

Active vaccination refers to the process of stimulating the patient's own immune system to drive an anti-tumor response. The major attraction of this approach is the potential to generate immunological memory, which may protect against relapsing tumors. Preclinical breast cancer vaccine strategies targeting Her2/neu and other breast cancer antigens established the proof of principle of the approach [5,6]. Encouragingly, early-phase clinical studies using peptides derived from the Her2/neu protein (E75 and GP2) have shown evidence of immunological responses $[7,8]$, and a more recent study suggests a potential clinical benefit in subsets of patients treated with the E75 peptide vaccine [9]. However, large phase III clinical trials of cancer vaccines that target solid tumors have largely failed to deliver major clinical benefits, despite the induction of humoral and cellular immune responses, indicating that improvements in vaccine design are clearly required [10].

At the heart of the immune system resides the dendritic cell (DC). Pivotal studies led by Ralph Steinman identified the DC as the key player involved with controlling the immune response. (Quite rightly, he was awarded a Nobel Prize for his work although he had passed away 
shortly before the names of the Prize winners were announced last year.) These studies of the biology of DCs have led to the identification of target molecules that may be exploited in vaccine design, including the C-type multilectin DEC205, which is expressed at high levels on lymphoid DCs. Proteins bound by DEC205 are internalized, proteolysed, and presented in the context of major histocompatibility complex class II proteins. Previous studies from the Steinman group exploited a DEC205specific monoclonal antibody to deliver the HIV and Epstein-Barr virus antigens to DCs, resulting in specific viral immune responses in mice, macaques, and human volunteers $[11,12]$. However, targeting antigen delivery to DEC205+ DCs alone is insufficient to fully mature DCs and thereby stimulate an immune response; DC maturation by the co-administration of agents such as polyinosinic:polycytidylic acid (poly I:C) with the DEC205 antibody-antigen fusion drives enhanced $\mathrm{CD}_{4}^{+} \mathrm{T}$-cell vaccine-driven responses [13].

These studies provide the rationale supporting a paper that was published by the Steinman group in the previous issue of Breast Cancer Research and details the construction and activity of a fusion protein consisting of the antiDEC205 antibody linked to the extracellular domain of Her2/neu [1]. In that study, Wang and colleagues confirm that mice vaccinated with the DEC205-Her2 fusion protein in combination with poly I:C develop strong Her2-specific antibody and CD4+ $\mathrm{T}$-cell responses while the fusion protein also drove antigen-specific $\mathrm{CD} 8^{+} \mathrm{T}$-cell responses as a result of cross-priming [1]. The critical result in that study was the relative potency of the fusion protein; as little as $2.7 \mu \mathrm{g}$ of Her2/neu protein was sufficient to induce a tumor-protective effect [1]. This observation strongly supports the further development of the DEC205-Her2 fusion protein vaccine and also suggests that less vaccine would be required for clinical study with implicit potential cost reductions.

However, the road to a successful cancer vaccine is long. Inducing vaccine responses in the mouse is an important prerequisite to confirm that the basic vaccine is functional. Human tumor antigens such as Her2/neu are not present in the mouse and, consequently, are not subject to immune regulation as would be expected in the patient with breast cancer. Breaking immunological tolerance is essential to permit immune responses against 'self' tumor-associated antigens such as Her2/neu. Vaccines targeting self-antigens in the mouse confirm that immunological tolerance blunts vaccine-induced T-cell responses [14]. Consequently, testing the potency of the DEC205-Her2 fusion protein in the Her2/neu transgenic model would be an important next stage to determine the potency of this vaccine in breaking immunological tolerance. However, Her2/neu-specific $\mathrm{T}$-cell responses and antibody responses have been documented in patients with Her2/neü tumors [15], and patients treated with peptide-based vaccines have mounted HER2/neu-specific immune responses [7,9], implying that overcoming immunological regulation of Her2/neu in patients with breast cancer is feasible.

Mouse preclinical model systems are limited in their relevance to the human situation. The successful development of the vaccine will be reliant upon optimizing the DC maturation adjuvant to be used in conjunction with the DEC205-Her2 protein and will also have to consider how the patient's immune system and tumor are affected by previous therapies. There is evidence that the antitumor immune response can be either enhanced or abrogated by altering the schedule of different chemotherapeutic agents. It may therefore be possible to enhance the anti-tumor immune response induced by vaccine therapy by optimizing the delivery of standard therapies [16]. Overall, the identification of a potent protein-based Her2/neu vaccine provides a refinement of vaccine development and warrants further investigation.

Abbreviations

DC, dendritic cell; poly I:C, polyinosinic:polycytidylic acid.

Competing interests

The authors declare that they have no competing interests.

Published: 30 May 2012

References

1. Wang B, Zaidi N, He LZ, Zhang L, Kuroiwa JM, Keler T, Steinman RM: Targeting of the non-mutated tumor antigen HER2/neu to mature dendritic cells induces an integrated immune response that protects against breast cancer in mice. Breast Cancer Res 2012, 14:R39.

2. Gianni L, Dafni U, Gelber RD, Azambuja E, Muehlbauer S, Goldhirsch A, Untch M, Smith I, Baselga J, Jackisch C, Cameron D, Mano M, Pedrini JL, Veronesi A,Mendiola C, Pluzanska A, Semiglazov V, Vrdoljak E, Eckart MJ, Shen Z, Skiadopoulos G, Procter M, Pritchard KI, Piccart-Gebhart MJ, Bell R; Herceptin Adjuvant(HERA) Trial Study Team: Treatment with trastuzumab for 1 year after adjuvant chemotherapy in patients with HER2-positive early breast cancer: a 4-year follow-up of a randomised controlled trial. Lancet Oncol 2011, 12:236-244.

3. Smith I, Procter M, Gelber RD, Guillaume S, Feyereislova A, Dowsett M, Goldhirsch A, Untch M, Mariani G, Baselga J, Kaufmann M, Cameron D, Bell R, Bergh J,Coleman R, Wardley A, Harbeck N, Lopez RI, Mallmann P, Gelmon K, Wilcken N, Wist E, Sánchez Rovira P, Piccart-Gebhart MJ; HERA study team: 2-year follow-up of trastuzumab after adjuvant chemotherapy in HER2positive breast cancer: a randomised controlled trial. Lancet 2007, 369:29-36.

4. Slamon DJ, Leyland-Jones B, Shak S, Fuchs H, Paton V, Bajamonde A, Fleming T, Eiermann W, Wolter J, Pegram M, Baselga J, Norton L: Use of chemotherapy plus a monoclonal antibody against HER2 for metastatic breast cancer that overexpresses HER2. N Engl J Med 2001, 344:783-792.

5. Ross JS, Slodkowska EA, Symmans WF, Pusztai L, Ravdin PM, Hortobagyi GN: The HER-2 receptor and breast cancer: ten years of targeted anti-HER-2 therapy and personalized medicine. Oncologist 2009, 14:320-368.

6. Wright SE: Immunotherapy of breast cancer. Expert Opin Biol Ther 2012, 12:479-490.

7. Clive KS, Tyler JA, Clifton GT, Holmes JP, Ponniah S, Peoples GE, Mittendorf EA: The GP2 peptide: A HER2/neu-based breast cancer vaccine. J Surg Oncol 2012, 105:452-458

8. Mittendorf EA, Holmes JP, Ponniah S, Peoples GE: The E75 HER2/neu peptide vaccine. Cancer Immunol Immunother 2008, 57:1511-1521.

9. Mittendorf EA, Clifton GT, Holmes JP, Clive KS, Patil R, Benavides LC, Gates JD, Sears AK, Stojadinovic A, Ponniah S, Peoples GE: Clinical trial results of the 
HER-2/neu (E75) vaccine to prevent breast cancer recurrence in high-risk patients: From US Military Cancer Institute Clinical Trials Group Study I-01 and I-02. Cancer 2012, 118:2594-2602.

10. Schlom J: Therapeutic cancer vaccines: current status and moving forward. J Natl Cancer Inst 2012, 104:599-613.

11. Trumpfheller C, Longhi MP, Caskey M, Idoyaga J, Bozzacco L, Keler T, Schlesinger SJ, Steinman RM: Dendritic cell-targeted protein vaccines: a novel approach to induce T-cell immunity. I Intern Med 2012, 271:183-192.

12. Gurer C, Strowig T, Brilot F, Pack M, Trumpfheller C, Arrey F, Park CG, Steinman RM, Munz C: Targeting the nuclear antigen 1 of Epstein-Barr virus to the human endocytic receptor DEC-205 stimulates protective T-cell responses. Blood 2008, 112:1231-1239.

13. Longhi MP, Trumpfheller C, Idoyaga J, Caskey M, Matos I, Kluger C, Salazar AM, Colonna M, Steinman RM: Dendritic cells require a systemic type I interferon response to mature and induce CD4+Th1 immunity with poly IC as adjuvant. J Exp Med 2009, 206:1589-1602.

14. Castro FV, Al-Muftah M, Mulryan K, Jiang HR, Drijfhout JW, Ali S, Rutkowski AJ, Kalaitsidou M, Gilham DE, Stern PL: Regulation of autologous immunity to the mouse $5 \mathrm{~T} 4$ oncofoetal antigen: implications for immunotherapy. Cancer Immunol Immunother 2011 Nov 30. [Epub ahead of print].

15. Disis ML, Calenoff E, McLaughlin G, Murphy AE, Chen W, Groner B, Jeschke M,Lydon N, McGlynn E, Livingston RB, Moe R, Cheever MA: Existent T-cell and antibody immunity to HER-2/neu protein in patients with breast cancer. Cancer Res 1994, 54:16-20.

16. Park S, Jiang Z, Mortenson ED, Deng L, Radkevich-Brown O, Yang X, Sattar H, Wang Y, Brown NK, Greene M, Liu Y, Tang J, Wang S, Fu YX: The therapeutic effect of anti-HER2/neu antibody depends on both innate and adaptive immunity. Cancer Cell, 18:160-170

doi:10.1186/bcr3184

Cite this article as: Armstrong AC, Gilham DE.: Targeting breast cancer vaccines to dendritic cells: improved immunological responses with less protein? Breast Cancer Research 2012, 14:106. 